\title{
Gold in the Jinya Carlin-type Deposit: Characterization and Implications
}

\author{
Youqin (Joe) Zhou ${ }^{1)}$ and Kuiren Wang ${ }^{2)}$ \\ ${ }^{1)}$ SGS Lakefield Research, P.O. Box 4300, 185 Concession Street, Lakefield, ON KOL 2H0, Canada \\ ${ }^{2)}$ Department of Earth \& Space Sciences, University of Science \& Technology of China, Hefei 230026, China
}

Gold in the Jinya Carlin-type deposit, assaying $6.27 \mathrm{~g} / \mathrm{t} \mathrm{Au}$, was characterized using a comprehensive mineralogical and analytical approach which includes optical microscopy and several advanced microbeam techniques. Each gold carrier was quantified independently. Gold in the Jinya ore occurred as microscopic gold and submicroscopic gold. Submicroscopic gold, primarily in the form of solid solution gold, was carried mainly by arsenopyrite (accounting for $77 \%$ of the gold assay), and to a lesser extent $(\sim 16 \%)$ in arsenic-rich fine-grained and microcrystalline pyrite. Native gold accounted for $6 \%$ of the gold assay. Gold carried in cinnabar and rock minerals is insignificant. Gold deportment shows that (1) arsenopyritization and pyritization can be used as indication of mineralization for the further exploration in the Jinya district, and (2) gold in sulfides is not amenable to direct cyanidation, but can be recovered by flotation of a sulfide concentrate and then cyanidation with a pretreatment process.

\section{Introduction}

According to the mode of occurrence, gold can be classified into three categories: microscopic gold, submicroscopic gold and surface-bound gold. Microscopic gold, also known as visible gold, comprises native gold, electrum, gold alloys, gold tellurides, gold antimonide, gold bismuthite, gold sulfides, gold selenides, gold sulfotellurides and gold sulfoselenides etc. Native gold (Au) and electrum ( $\mathrm{Au}, \mathrm{Ag}$ ), found in various types of gold deposits, are the two most common and most important gold minerals. Other gold minerals with economic significance in some gold deposits include kustelite $(\mathrm{Ag}, \mathrm{Au})$, auricupride $\left(\mathrm{Cu}_{3} \mathrm{Au}\right)$, tetraauricupride $(\mathrm{CuAu})$, calaverite $\left.(\mathrm{AuTe})_{2}\right)$, krennerite $\left((\mathrm{Au}, \mathrm{Ag}) \mathrm{Te}_{2}\right)$, aurostibite $\left(\mathrm{AuSb}_{2}\right)$ and maldonite $\left(\mathrm{Au}_{2} \mathrm{Bi}\right)$ etc (Boyle, 1979; Healy et al., 1990; Wang et al. 1994). Microscopic gold in primary ore occurs as pristine grains in varied size and shape in fractures and microfractures, or as attachments to and inclusions in other minerals. Gold that is invisible under optical microscope and scanning electron microscope is referred to as submicroscopic gold or invisible gold. Submicroscopic gold, commonly occurs as discrete particulate $(<0.1 \mu \mathrm{m}$ in diameter) within sulfide minerals (mainly in pyrite and arsenoppyrite), is the major form of gold in the Carlin-type gold deposits and other refractory gold ores (Hausen, 1981; Radtke, 1985; Hausen et al., 1986; Cabri et al., 1989; Wang et al., 1992, 1994). Gold concentration in pyrite can be several hundred ppm high, while that in arsenopyrite can be over 10,000 ppm (Chryssoulis et al., 1990). Other submicroscopic gold carriers include chalcopyrite (Cook et al., 1990), loellingite (Neumayr et al., 1993), marcasite, FeOx (in oxidized ores or calcines) and realgar (Wang et al., 1994), and clay minerals (Chao et al., 1987). Solid solution gold and colloidal gold are the two major forms of submicroscopic gold. Surface-bound gold is the gold that is adsorbed onto the surface of other minerals during the mineralization and subsequent oxidation or metallurgical processing. Principal surface gold carriers in the ore include $\mathrm{FeOx}$, 
stained quartz, carbonaceous matter and clay minerals. Characterizing gold in an ore is important in gold exploration and extraction metallurgy, particularly for the Carlin-type gold deposits. This is because the majority of gold in Carlin-type deposits occurs as invisible gold in other minerals which has to be characterized prior to metallurgical testwork.

\section{Characteristics of Carlin-type Deposits}

Unlike some widespread types of gold deposits, Carlin-type deposits only occur in certain regions within the Pacific rim such as the western United States, southwest China and some other locations (Radtke, 1985; Wang et al., 1994; Liu et al., 1994; Hofstra et al., 2000; Kerrich et al., 2000; Yakubchuk, 2000; Teal et al., 2002; Peters et al., 2002). In the western United States, more than 100 Carlin-type gold deposits and occurrences have been discovered since early 1960s with some becoming major gold producers (e.g. Carlin, Betze, Meikle and Deep Post) (Kerrich et al., 2000; Jory, 2002). They are restricted to a small part of the North American Cordillera, in northern Nevada and northwest Utah, and formed over a short interval of time (42-30 Ma) in the Tertiary (Hofstra et al., 2000). In the southwest China, including Yunnan, Guizhou, Guangxi, Hunan, Sichuan, Shaanxi and Gansu provinces, over 20 medium-sized to large Carlin-type deposits have been discovered in the past two decades. The gold mineralization in southwest China occurred along the margin of the Yantze Craton, and is mainly distributed in the southwest border (also known as the Dian-Qian-Gui Golden Triangle) and northwest border (also known as the ChuanGan-Shaan Golden Triangle) of the Yantze Craton (Wang et al., 1994; Liu et al., 1994; Peters et al., 2002).

Basically, Carlin-type gold deposits are characterized by (1) strong structural control of mineralization by faults and folds, (2) calcareous sedimentary host rocks of diverse facies, tigneous rocks, (3) decarbonation, argillization, silicification and sulfidation alterations, (4) submicron gold $(<0.2 \mu \mathrm{m})$ in association with pyrite, arsenian pyrite and arsenopyrite, and (5) geochemical signature of Au, As, Hg, Sb and Tl (Radtke, 1985; Wang et al., 1994; Liu et al., 1994; Hofstra et al., 2000).

Mineralogically, Carlin-type gold ore consists of about 40 minerals, and the mineralogy is basically the same in most deposits. Opaque minerals include native gold, pyrite, marcasite, arsenopyrite, realgar, orpiment, stibnite, cinnabar, and pyrrhotite. Non-opaque minerals comprise quartz, carbonates, clay minerals, albite, barite, carbonaceous matter and graphite. Lorandite $\left(\mathrm{TlAsS}_{2}\right)$ and ellisite $\left(\mathrm{Tl}_{3} \mathrm{AsS}_{3}\right)$ are also observed in some Carlin-type deposits in the western United States and southwest China, which are closely associated with gold mineralization (Radtke, 1985; Liu et al., 1994).

The mode of occurrence of gold in the Carlin-type deposit has been an interesting and important subject in gold mineralogy and extraction metallurgy, and extensively studied by numerous researchers since those deposits were found in the western United States in early 1960s, and a great deal of information on the occurrence of gold in various deposits has been acquired (Hausen, 1981, 1986; Chao et al., 1987; Hochella et al., 1987; Wang et al., 1992; Wang et al., 1994; Simon et al., 1999; Hong et al., 2000). The most important characteristic of gold in Carlin-type deposits is that the majority of gold in the ore occurs as submicroscopic gold, either in solid solution gold $(<0.01 \mu \mathrm{m})$ or colloidal gold $(0.01-0.1 \mu \mathrm{m})$, or both, in pyrite and arsenopyrite. Pyrite is the most common sulfide mineral and most important gold carrier in the Carlin-type deposits. The content of pyrite in the ore is about $5 \%$ on average. Morphologically, pyrite commonly occurs as coarsegrained, blastic, fine-grained and microcrystalline varieties (Figure 11). Coarse-grained pyrite often 
occurs as euhedral cubic or pyritohedron crystals, while fine-grained pyrite usually occurs as irregular granule or framboids. Compositionally, pyrite is characterized by its high As content and lower S/Fe (Wang et al., 1994). Zoned texture is observed in coarse pyrite in many Carlin-type gold deposits. In zoned pyrite, As and Au concentrates in the outer zone (Wells et al., 1973), while in fine-grained pyrite the distribution of $\mathrm{As}$ and $\mathrm{Au}$ is relatively homogeneous and a positive correlation between $\mathrm{Au}$ and $\mathrm{As}$ is often observed (Simon et al., 1999; this paper). In addition, pyrite in the Carlin-type deposits commonly contains high concentration of $\mathrm{Hg}$, Sb and $\mathrm{Tl}$ (Wang et al., 1994; Hofstra et al., 2000). In most Carlin-type deposits, pyrite is the major gold carrier, particularly the fine-grained arsenian pyrite often contains high content of submicroscopic gold (Bakken et al., 1991; Arehart et al., 1993; Wang et al. 1994). For example, fine-grained arsenian pyrite (up to $2 \mu \mathrm{m}$ in grain size) from Twin Creeks Carlin-type deposit contained 595-1,465 ppm $\mathrm{Au}$ (Simon et al., 1999). Arsenopyrite and marcasite in the Carlin-type deposit refractory ores also contain high concentration of gold. In certain Carlin-type deposits, such as the Jinya deposit in southwest China, $\mathrm{Au}$ in arsenopyrite is as high as 1044 ppm, making arsenopyrite the principal gold carrier in the ore (this paper). Comparable concentration of gold has been measured in arsenopyrite from other types of gold deposits (Cabri et al., 1989). Other sulfide minerals, including realgar, orpiment, stibnite and cinnabar, are often observed in the Carlin-type deposits, but no significant amount of gold has been detected in these minerals (Wang et al., 1994; this paper).

\section{Samples, Analytical Methods and Study Procedure}

The ore from the Jinya mine, Guangxi in southwestern China was selected for the study. The geology and mineralization were discussed by Wang et al. (1994). The Jinya mine is located in Fengshan County, Guangxi Zhuang Autonomous Region and within the Yunnan-Guizhou-Guangxi Golden Triangle. The orebodies at Jinya occur in sandstone, siltstone, and silty mudstone of the upper Banna Group (Middle Triassic). Three types of ores were identified: pyrite ore, arsenopyrite ore and pyrite-arsenopyrite ore. Alteration associated with gold mineralization included pyritization, arsenopyritization, carnonatization, realgari-zation and silicification. The chemical and mineralogical compositions of the Jinya ore were listed in Tables 1 and 2, respectively.

Table 1: Gold Assays and Head Analyses

\begin{tabular}{|c|c|c|c|c|}
\hline Sample Name & $\begin{array}{l}\mathrm{Au} \\
(\mathrm{g} / \mathrm{t})\end{array}$ & $\mathrm{Fe}(\%)$ & $\mathrm{S}(\%)$ & As $(\%)$ \\
\hline J01 Feed & 6.30 & 4.32 & 4.43 & 4.22 \\
\hline J02 Feed & 6.24 & - & - & - \\
\hline $\mathrm{J} 03-5 \mu \mathrm{m}$ & 4.57 & - & - & - \\
\hline $\begin{array}{c}\text { J03 -5um } \\
\text { CN Residue }\end{array}$ & 3.82 & - & - & - \\
\hline
\end{tabular}


Table 2: Mineralogical Composition

\begin{tabular}{|ccc|}
\hline Mineral Name & Chemic al Formula & $\begin{array}{c}\text { Abundance } \\
(\text { wt. } \%)\end{array}$ \\
Arsenopyrite & $\mathrm{FeAsS}$ & 2.5 \\
Pyrite & $\mathrm{FeS}_{2}$ & 7.4 \\
Realgar & $\mathrm{AsS}$ & 1.4 \\
Quartz & $\mathrm{SiO}_{2}$ & 45 \\
Silicates & - & 40 \\
Carbonates & $(\mathrm{Ca}, \mathrm{Fe}, \mathrm{Mg}, \mathrm{Mn})\left(\mathrm{CO}_{3}\right)_{1-2}$ & 3.0 \\
Sphalerite & $\mathrm{ZnS}$ & trace \\
Galena & $\mathrm{PbS}$ & trace \\
Chalcopyrite & $\mathrm{CuFeS}_{2}$ & trace \\
Covellite & $\mathrm{CuS}$ & trace \\
Pyrrhotite & $\mathrm{Fe}_{1-\mathrm{x}} \mathrm{S}$ & trace \\
Stibnite & $\mathrm{Sb}_{2} \mathrm{~S}_{3}$ & trace \\
Ilmenite & $\mathrm{FeTiO}_{2}$ & trace \\
Hematite & $\mathrm{Fe}_{2} \mathrm{O}_{3}$ & trace \\
Rutile & $\mathrm{TiO}_{2}$ & trace \\
Barite & $\mathrm{BaSO}_{4}$ & trace \\
Mative Arsenic & $\mathrm{As}$ & trace \\
\hline
\end{tabular}

A comprehensive mineralogical and analytical approach, including reflected light microscope and several advanced microbeam techniques, was used for the current study. A reflected light microscope was used to search for visible gold minerals and to determine the general mineralogical composition. The model X-650 scanning electron microscope (SEM) equipped with two wavelength dispersive spectrometers was used to search for micron-size gold particles. A JEOL 733 electron microprobe (EMP) with wavelength-dispersion spectrometer was used to analyze gold particles and the major sulfide minerals for their compositions. Polished blocks were examined under ore microscope and interested areas were chosen for proton-induced X-ray emission ( $\mu$-PIXE) analysis and mapping to determine the distribution of $\mathrm{Au}, \mathrm{As}, \mathrm{S}$ and $\mathrm{Fe}$ in individual sulfide minerals and hosting silicates. Samples for secondary ion mass spectrometry (SIMS) analysis were prepared as polished grain mounts in $22 \mathrm{~mm}$ diameter of epoxy with approximately $15 \mathrm{wt} \%$ graphite added, and were then examined under microscope to determine the abundance of pyrite and arsenopyrite morphological types and to select target mineral particles. The quantitative analyses of $\mathrm{Au}^{197}, \mathrm{As}^{75}$, $\mathrm{S}^{34}$ and $\mathrm{Fe}^{56}$ in different types of pyrite and arsenopyrite were performed on a CAMECA IMS-3f SIMS with a cesium primary beam size of about $20 \mu \mathrm{m}$. The overall sampling depth of SIMS is 0.5$1 \mu \mathrm{m}$ and the minimum detection limit (MDL at 2?) is $0.3 \mathrm{ppm}$. Fe and $\mathrm{S}$ were also analyzed to monitor SIMS instrumental conditions during the analysis. Analytical procedures and standardization for gold in the SIMS analysis are given by Chryssoulis et al. (1987, 1989). Calibration was done by external standardization using gold-implanted pyrite and arsenopyrite (Chryssoulis et al., 1989). Time-of-flight resonance ionization mass spectrometry (TOF-RIMS) with a minimum detection limit of $10 \mathrm{ppb}$ for gold was used to detect and quantify gold in realgar. 
Intensive cyanidation was performed on $-5 \mu \mathrm{m}$ fraction to determine the amount of cyanidable gold. The procedure employed in the current study was depicted in Figure 1.

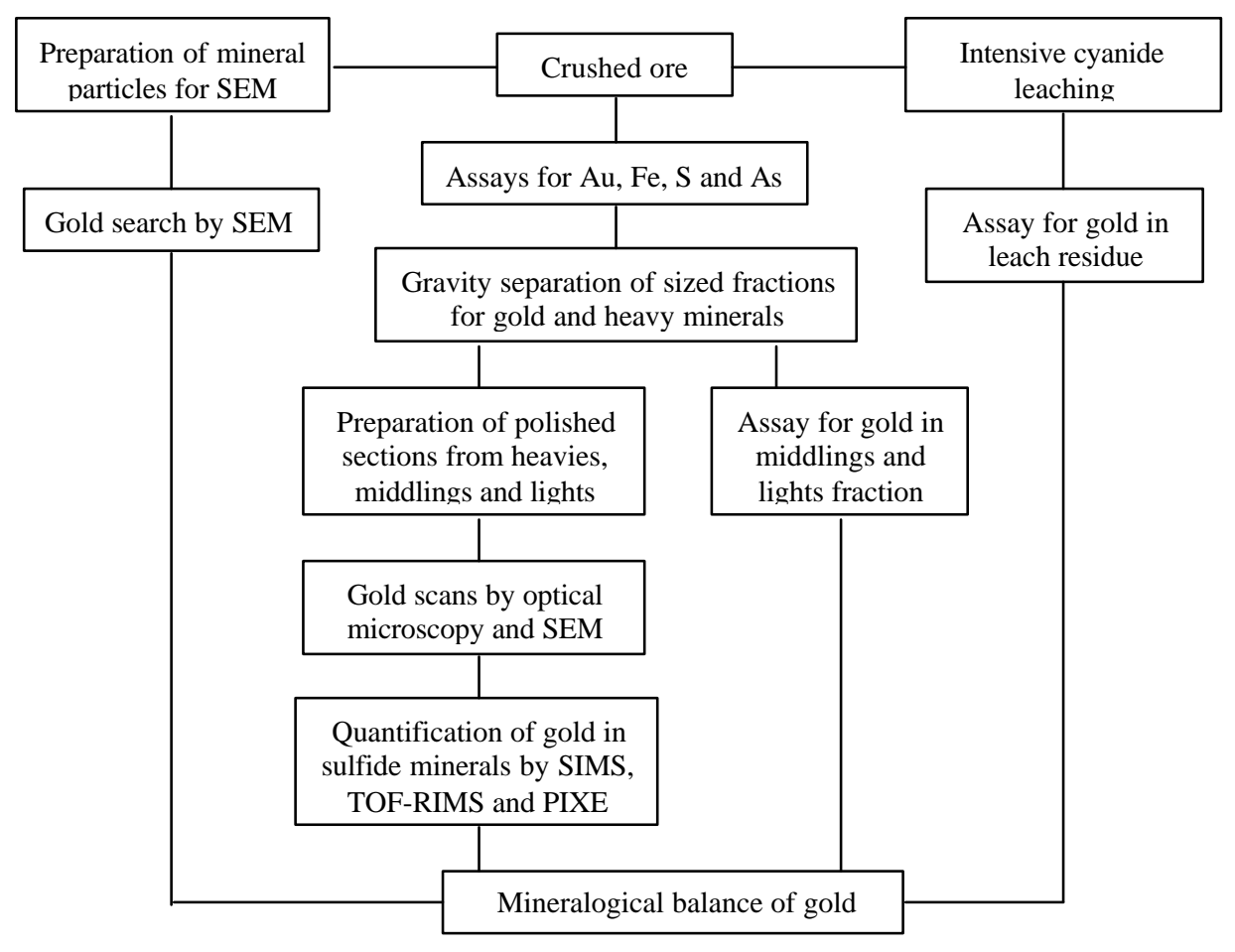

Figure 1: Study Procedure 


\section{Results}

\section{Microscopic examination}

Several dozen polished sections made from concentrates, middlings and tails of sized fractions were scanned under reflected light microscope at 500X. Four gold particles (Figure 2) less than 20 $\mu \mathrm{m}$ in size were found. Electron microprobe analysis showed that these gold particles are native gold with 17.3 wt.\% of Ag.
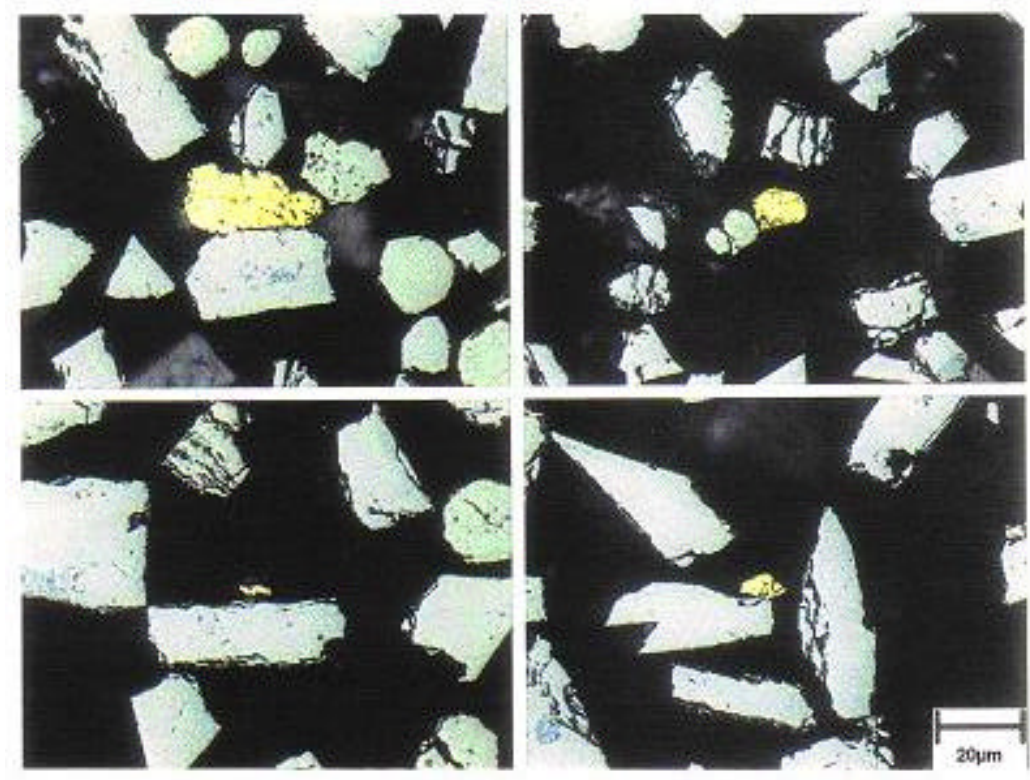

Figure 2: Microscopic gold particles (bright yellow). Pyrite: pale yellow; Arsenopyrite: greenish white.

\section{SEM examination}

Systematic scans for fine-grained gold particles were conducted on both polished blocks and individual pyrite, arsenopyrite and realgar particles selected from crushed samples under a binocular microscope. No gold was found in 50 polished blocks. Forty micron-size gold particles $(1-10 \mu \mathrm{m}$ in size) were observed on pyrite and arsenopyrite, occurring in microfissures, defect sites or detrital materials on the surface of anhedral pyrite and arsenopyrite. Figure 3 shows that a micrograined gold particle $(1 \times 2 \mu \mathrm{m})$ occurred in a void on the surface of an arsenopyrite particle. Figure 4 shows two micrograined gold particles observed in the microfissures on pyrite. A gold particle with $\sim 15$ wt.\% of $\mathrm{Hg}$ was shown in Figure 5. These micrograined gold particles are amenable to direct cyanidation and will dissolve to completion during conventional cyanidation. Intensive cyanidation conducted in the current study showed that approximately $6 \mathrm{wt} \%$ of gold in the Jinya ore is leachable. 

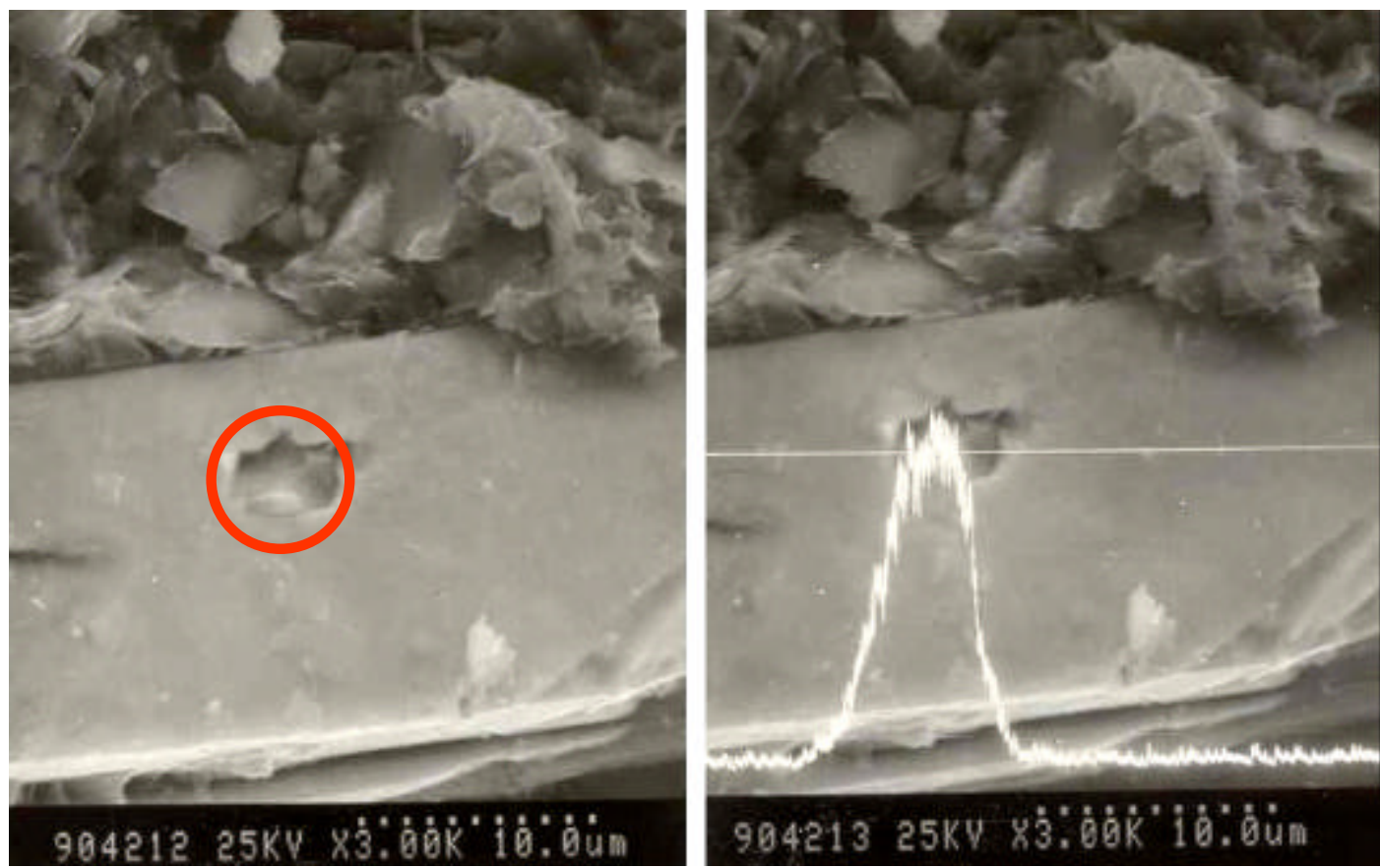

Figure 3: Micron-size gold particle (1x2 um, in the centre of red circle) occurred in a void on arsenopyrite.
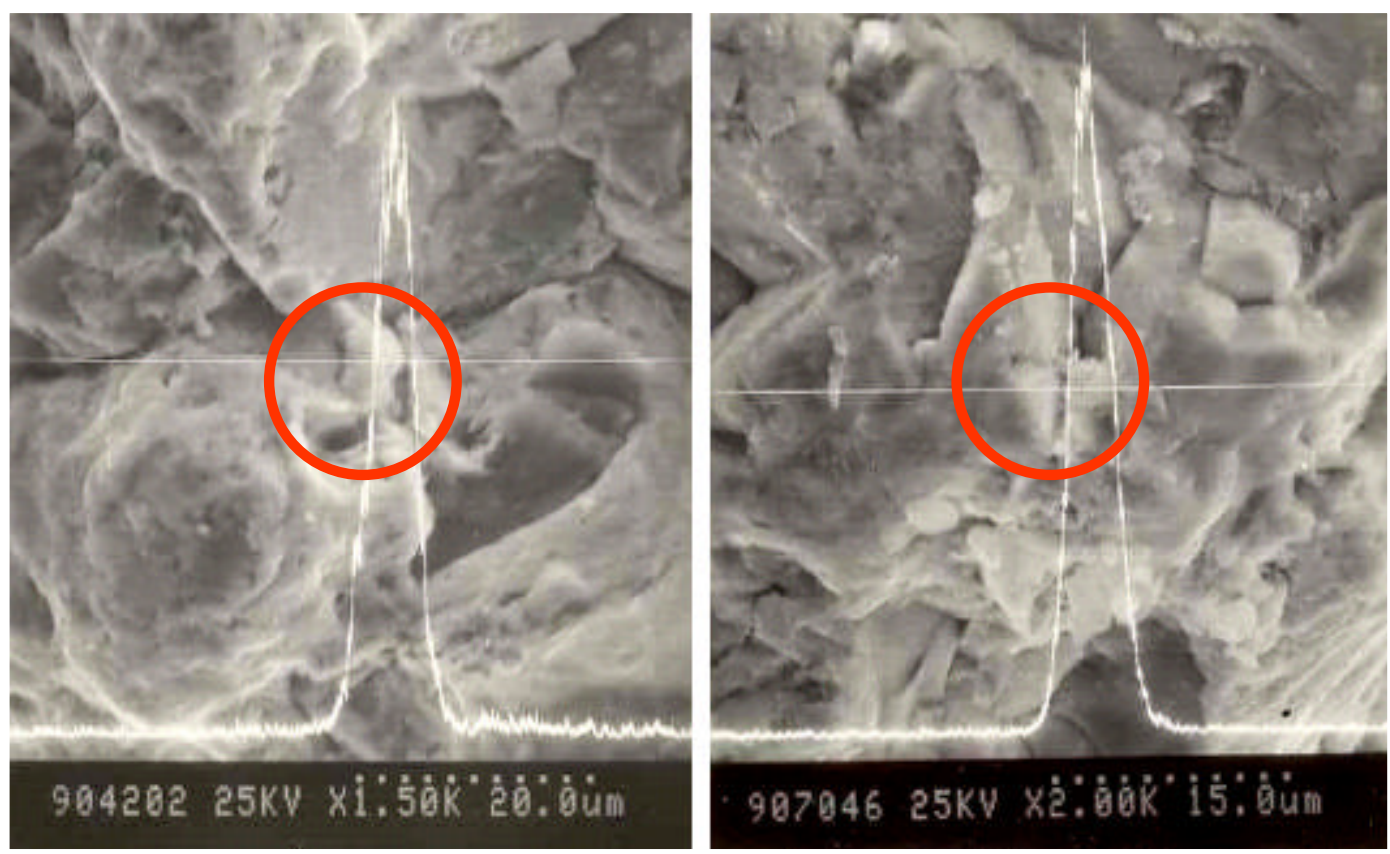

Figure 4: Micron-size gold particles (left: 4x8 um, right: 3x3 um, in the centre of red circle) occurred in fractures in pyrite. 

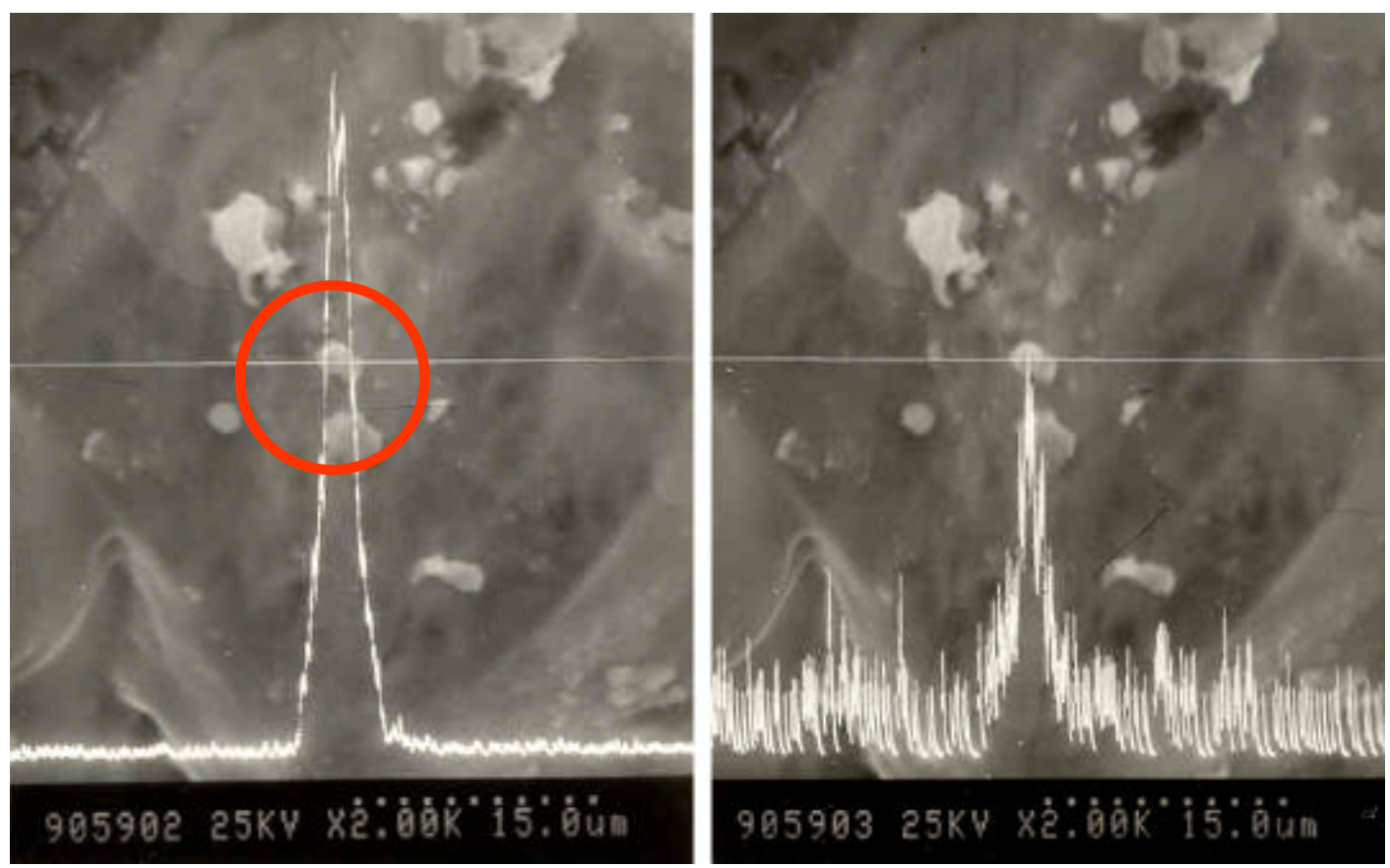

Figure 5: Micron-size Hg-bearing gold particle ( $2 \times 3$ um, in the centre of red circle) on pyrite. The EDS spectrum on the left is for $\mathrm{Au}$, and that on the right is for $\mathrm{Hg}$.

\section{PIXE mapping}

PIXE analysis is a multi-element and nondestructive technique with a small beam size $(\sim 5 \mu \mathrm{m})$ and low detection limit for gold at ppm level. In addition to quantification capability, PIXE can also be used to obtain two-dimension distribution images of gold and other elements in sulfide and rock minerals. In the current study, PIXE mapping of $\mathrm{Au}, \mathrm{Fe}, \mathrm{S}$ and As were performed on numerous polished blocks that contain pyrite, arsenopyrite and realgar in quartz and/or silicate. Figures 6-8 showed that the distribution and concentration of gold in the mapped area is closely associated with that of arsenic, sulfur and iron, which indicates that gold was contained in pyrite, arsenopyrite and realgar. No gold was detected in host rock minerals, which is consistent with fire assays of gravity separated tails and binaries (Figure 9), implying that gold was contained in sulfides. 

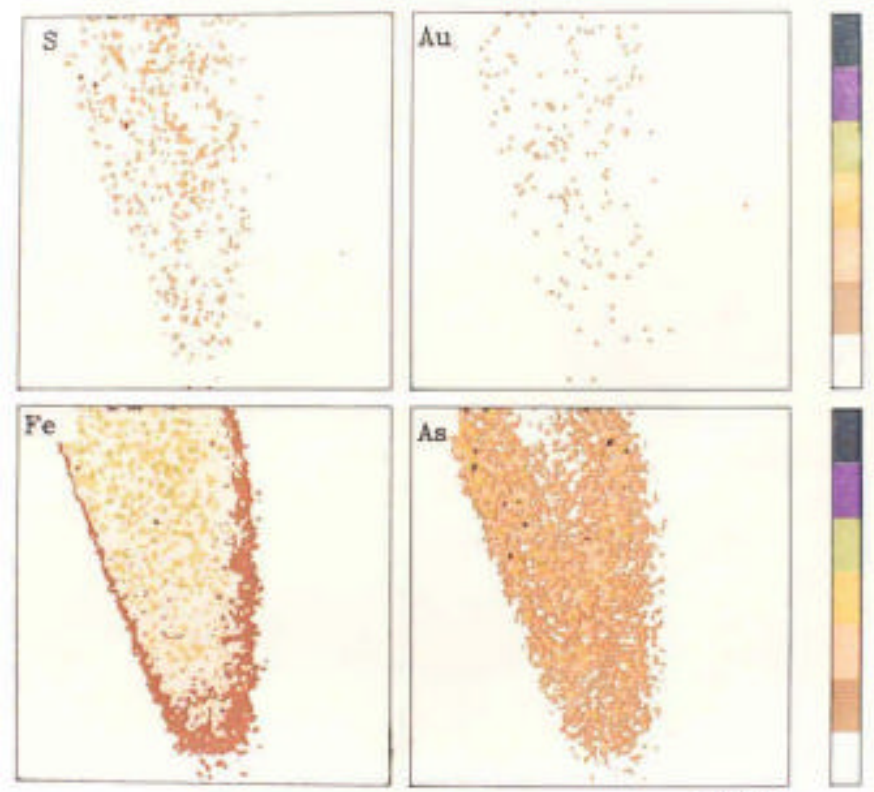

500 em

Figure 6: PIXE element distribution map of pyrite, which shows gold distributed only in pyrite. No gold was detected in host rock minerals. Scale bar on the right side represents the relative concentration. From top to bottom, the concentration decreases.

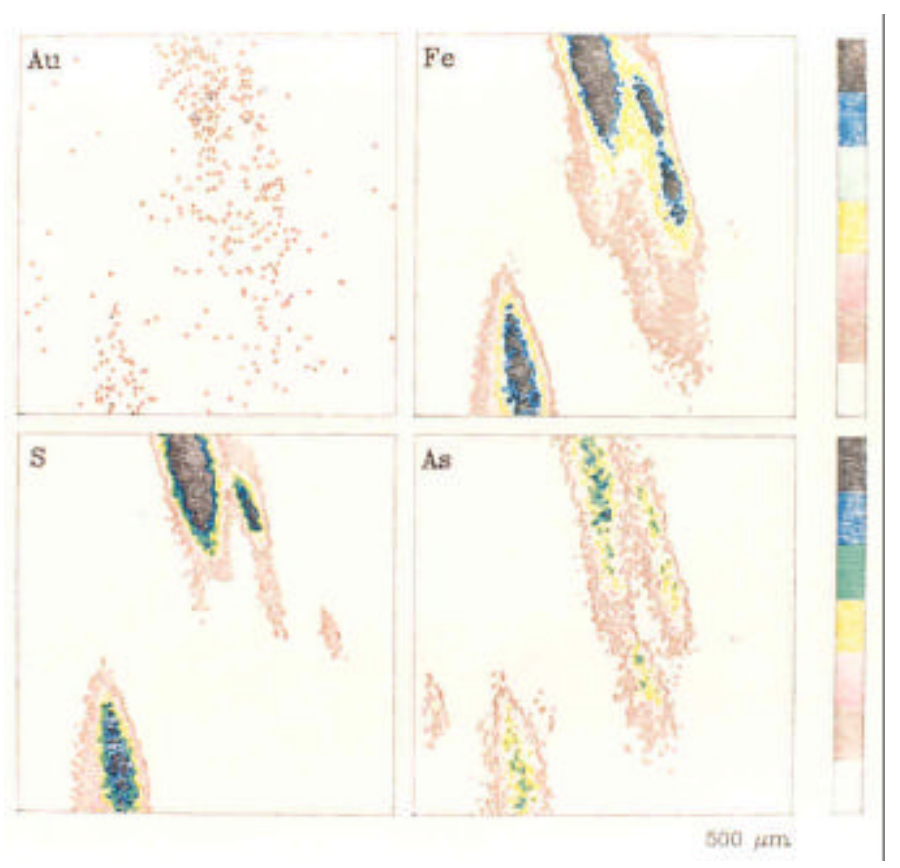

Figure 7: PIXE element distribution map of arsenopyrite. Same as in pyrite, gold distributed only in arsenopyrite. Scale bar on the right side represents the relative concentration. From top to bottom, the concentration decreases. 
Vol.2, No.2
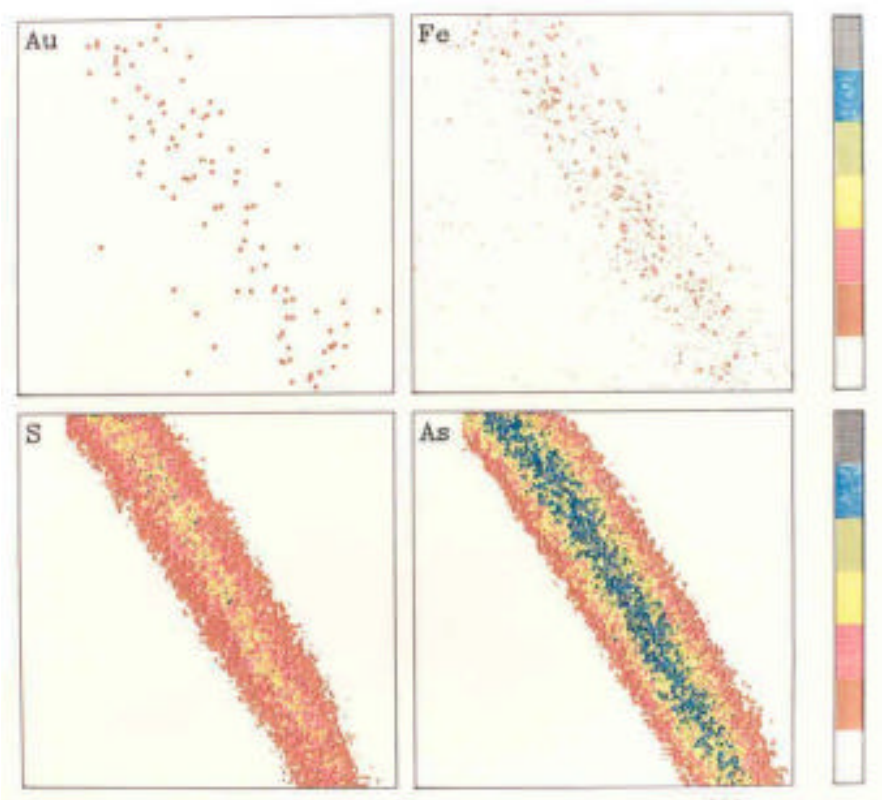

Figure 8: PIXE element distribution map of realgar. Gold distributed only in realgar. Scale bar on the right side represents the relative concentration. From top to bottom, the concentration decreases.

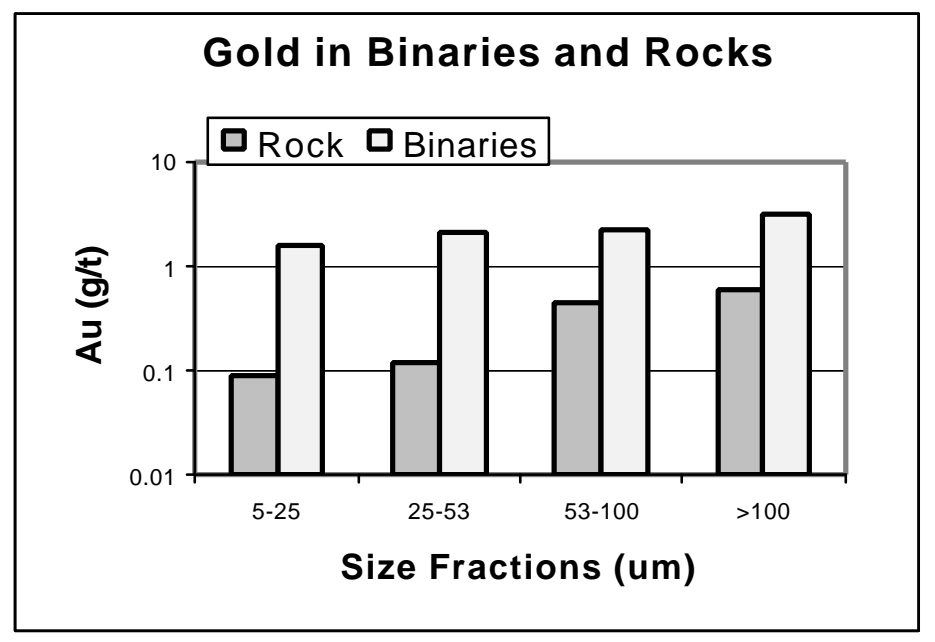

Figure 9: Gold assays of the sized rock mineral and rock/sulfide fractions. The systematic decrease of gold concentration in the rock mineral fraction reflects increase of sulfide liberation. However, gold is primarily concentrated in the rock/sulfide binaries, which constitute the second in importance gold carrier in the Jinya ore. 


\section{SIMS analysis}

The $\mathrm{Au}$ content in arsenopyrite ranges from 0.10 to $1044 \mathrm{ppm}$ (Table 3) with an average of 195 ppm. Arsenopyrite is one of the two principal "invisible" gold carrier-minerals in the Jinya ore; the other one is arsenian pyrite, which ranges from 0.31 to $122 \mathrm{ppm}$ (Table 4) and averages $13.2 \mathrm{ppm}$. Among the four types of arsenopyrite, blastic and fine-grained particles are the two varieties that contain high content of gold (Figure 10); while fine-grained and micro-crystalline pyrites are the two major gold carriers among the pyrite varieties (Figure 11).

Using SIMS analysis, Cook et al. (1990) and Simon et al. (1999) demonstrated a positive correlation between the concentration of "invisible" $\mathrm{Au}$ and $\mathrm{As}$ in arsenian pyrite. In the current study, a positive correlation between $\mathrm{Au}$ and As in arsenian pyrite from Jinya ore was also indicated by SIMS analyses (Figure 12), which is consistent with the distribution of gold and arsenic in pyrite demonstrated by PIXE mapping (Figure 6).

Table 3: Submicroscopic Gold Content of Arsenopyrite

\begin{tabular}{|ccc|}
\hline Grain \# & Morphological Type & Au (ppm) \\
1 & Coarse & 0.44 \\
2 & & 1.64 \\
3 & & 0.17 \\
4 & & 0.89 \\
5 & & 1.54 \\
6 & & 0.64 \\
\hline
\end{tabular}

Table 4: Submicroscopic Gold Content of Pyrite

\begin{tabular}{|cccc|}
\hline Grain \# & Morphological Type & Au (ppm) & $\begin{array}{c}\text { As } \\
(\mathbf{w t} . \%)\end{array}$ \\
1 & Coarse/Blastic & 0.31 & 1.71 \\
2 & & 4.25 & 1.77 \\
3 & & 0.43 & 3.03 \\
4 & & 0.44 & 4.33 \\
5 & & 0.51 & 6.07 \\
6 & & 3.90 & 0.68 \\
7 & & 6.60 & 2.95 \\
8 & & 2.02 & 0.69 \\
\hline
\end{tabular}



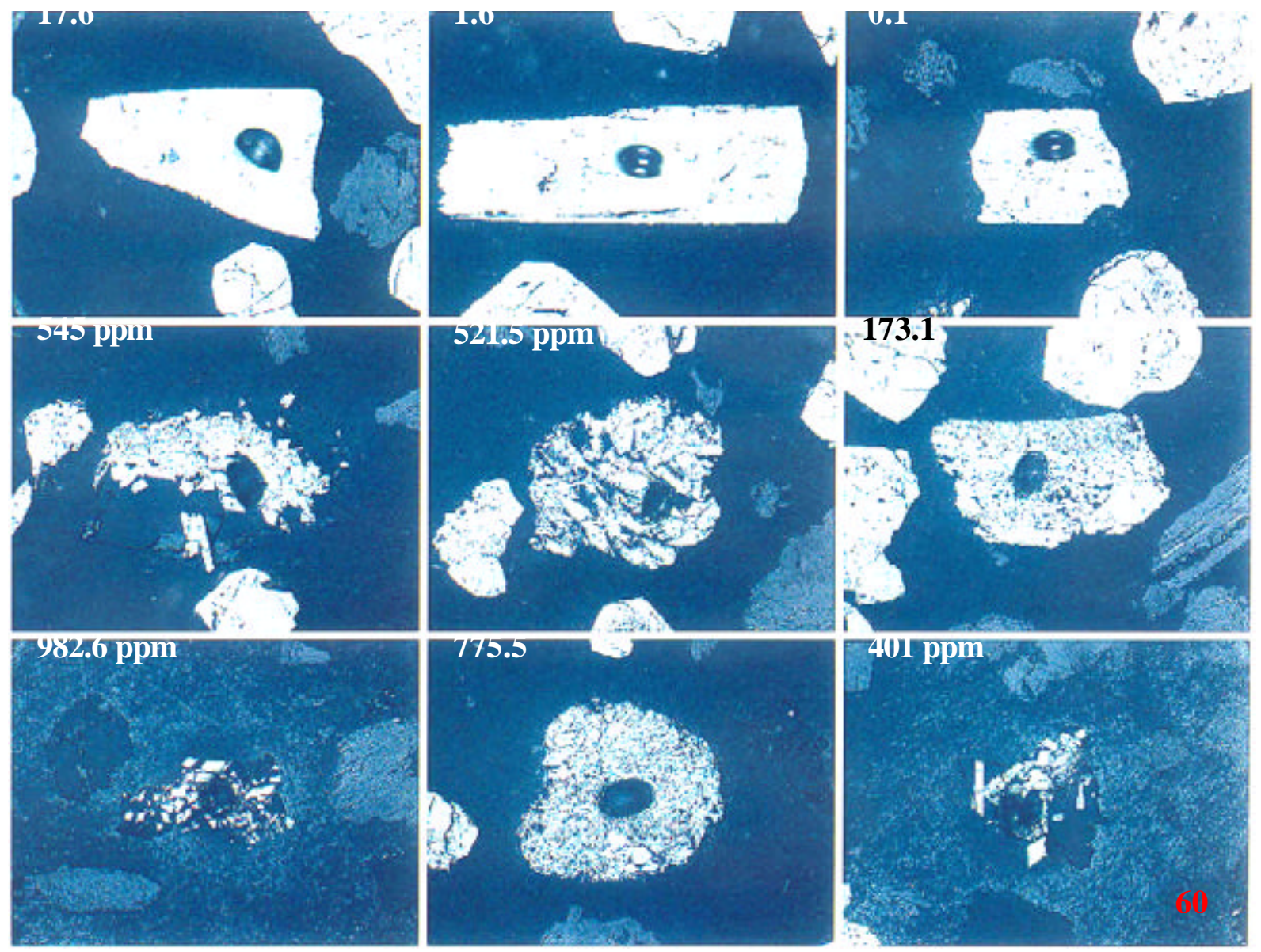

Figure 10: Morphological types of gold-bearing arsenopyrite. Coarse-grained arsenopyrite (top three) contained very low content of gold, while blastic and fine-grained varieties (middle and bottom rows) contained high content of gold. The deep color pit in the centre of each analyzed particle is the analytical spot of SIMS, which is about 20 um in diameter. 

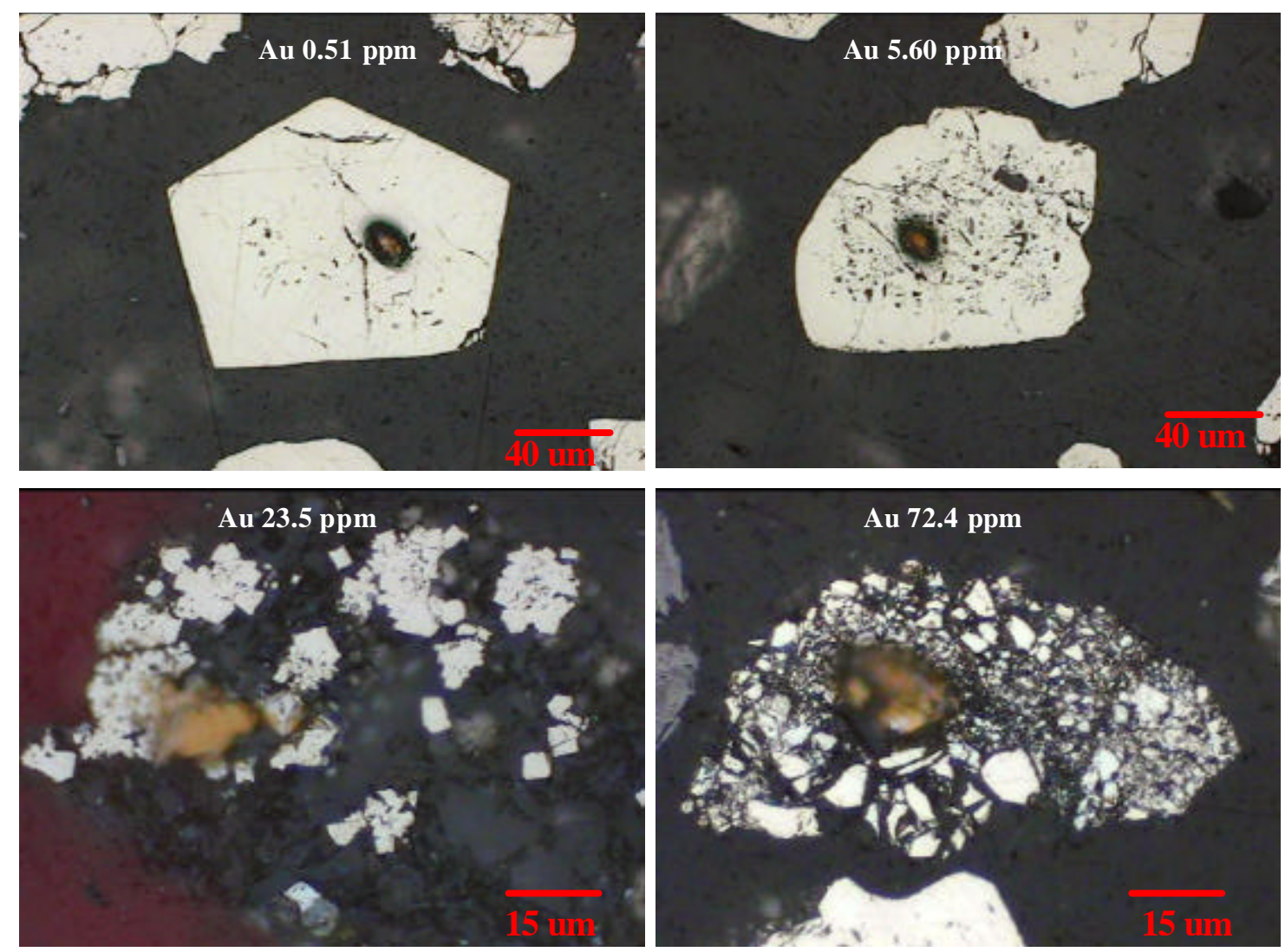

Figure 11: Morphological types of gold-bearing pyrite. Fine-grained and microcrystalline pyrites are the two varieties which contained high content of gold. The deep color pit in the centre of each analyzed particle is the analytical spot of SIMS.

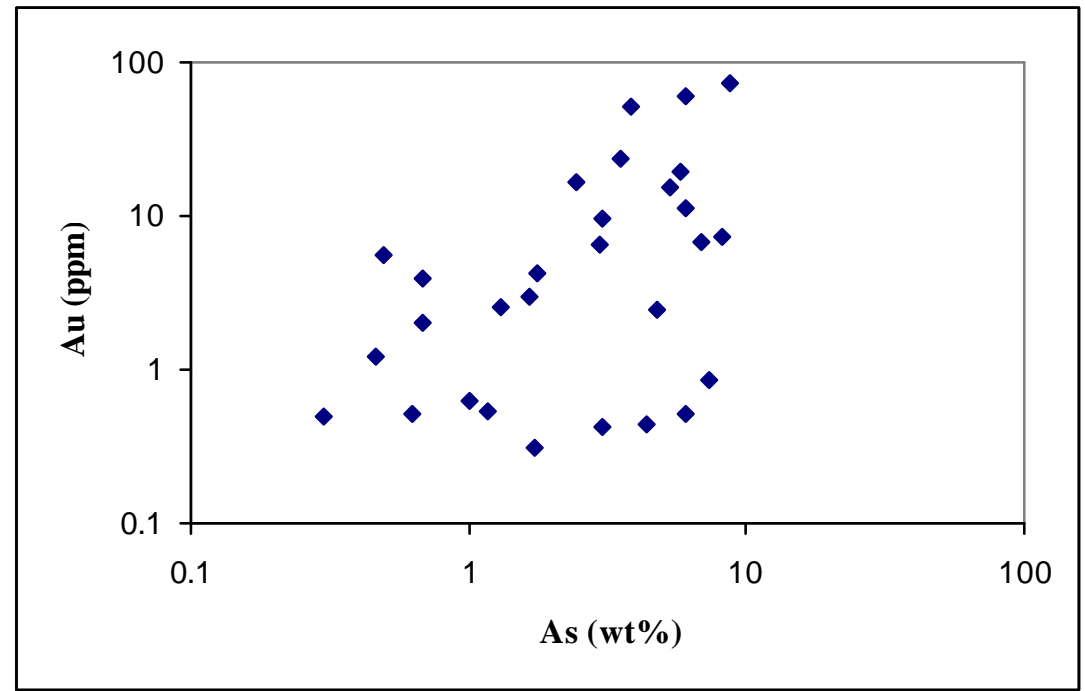

Figure 12: Correlation between submicroscopic gold and arsenic in pyrite from Jinya ore. 


\section{TOF-RIMS analysis}

TOF-RIMS is a microbeam analytical technique that allows for the identification and quantification of atomic species in very small quantities, and has been demonstrated capable of providing quantitative ultra trace element analysis of precious metals in minerals. The detection limit for gold can be $10 \mathrm{ppb}$ or even lower (Stamen et al., 1999). 13 realgar particles selected from Jinya ore were analyzed by TOF-RIMS, ranges from $0.37-1.70 \mathrm{ppm} \mathrm{Au}$ with an average $0.68 \mathrm{ppm} \mathrm{Au}$ (Table 5). TOF-RIMS analysis also showed that gold in realgar occurred as colloidal gold.

Table 5: Submicroscopic Gold Concentration of Realgar

\begin{tabular}{|cc|}
\hline Grain \# & Au (ppm) \\
1 & 0.44 \\
2 & 0.51 \\
3 & 0.65 \\
4 & 0.65 \\
5 & 0.85 \\
6 & 0.37 \\
7 & 0.65 \\
8 & 0.72 \\
9 & 0.72 \\
10 & 0.37 \\
11 & 0.44 \\
12 & 0.72 \\
13 & 1.70 \\
Average & 0.68 \\
\hline
\end{tabular}

\section{Discussion and Conclusions}

Results from microscopic gold scans, SEM searching, PIXE mapping, and SIMS and RIMS analyses demonstrated that there are two forms of gold occurring in the Jinya ore: microscopic gold and submicroscopic gold. Microscopic gold, occurring as fine- to medium-grained native gold and as micron-size gold particles, accounted for $6 \%$ of the gold assay. This part of gold can be recovered by conventional cyanidation. Submicroscopic gold was mainly carried in sulfide minerals (Figure 13), principally in arsenopyrite (accounting for $77 \%$ of the gold assay), and to a lesser extent in pyrite (accounting for approximately $16 \%$ of the gold assay). Gold in realgar only accounts for $0.2 \%$ due to its extremely low gold concentration. Gold in rock minerals accounted for 1\%. Gold deportment is depicted in Figure 14. 


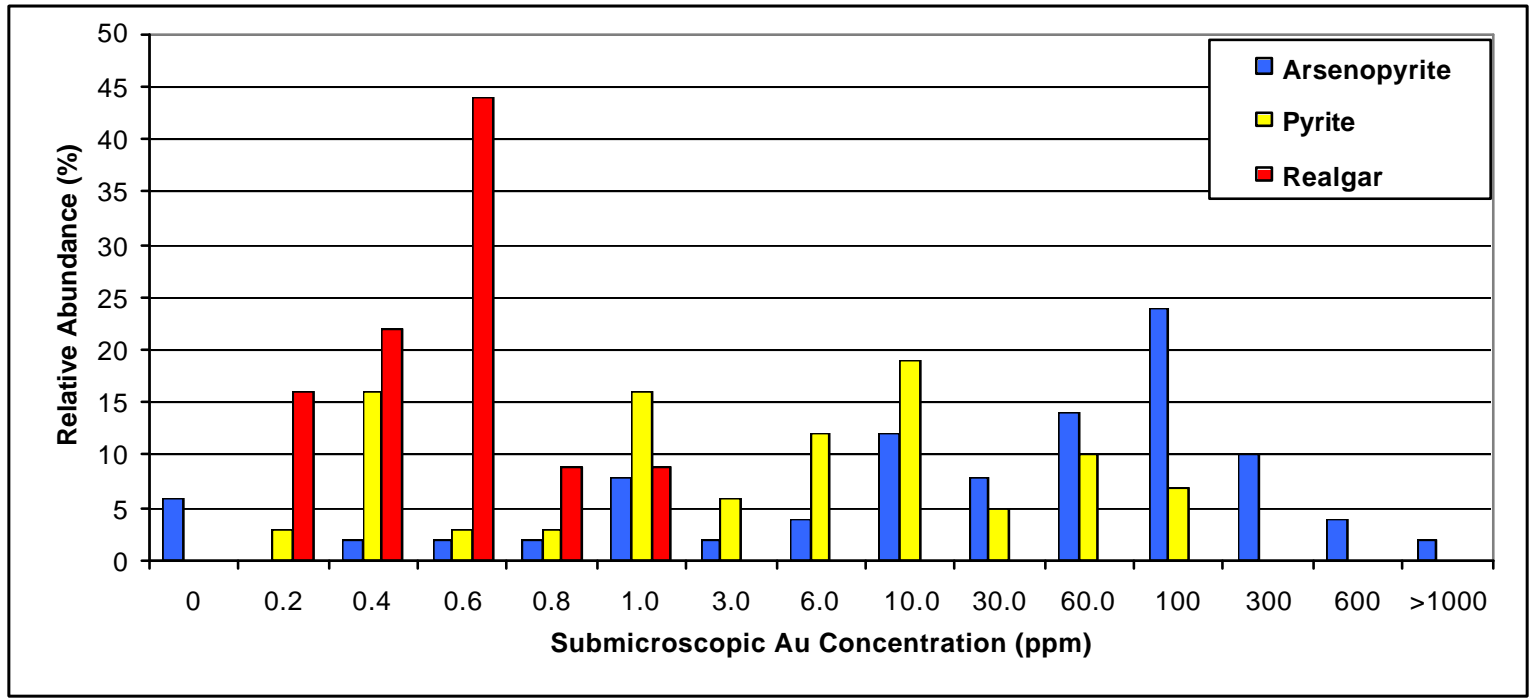

Figure 13: Gold concentration: arsenopyrite $(195 \mathrm{ppm})>$ pyrite $(13.2 \mathrm{ppm})>$ realgar $(0.68 \mathrm{ppm})$

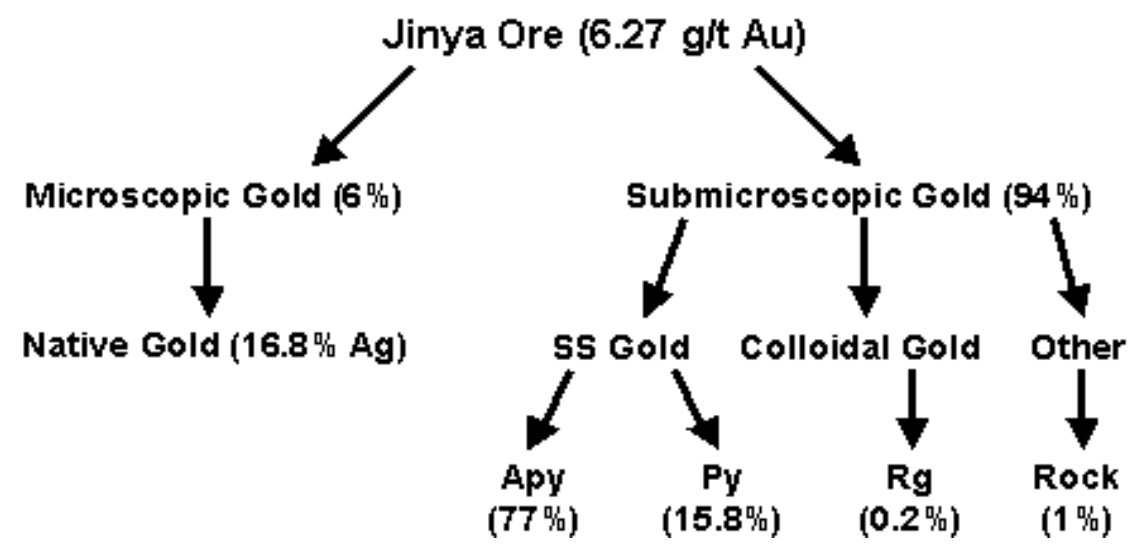

Figure 14: Deportment of gold in the Jinya ore. SS - solid solution. Apy - arsenopyrite; Py - pyrite; $\mathrm{Rg}$ - realgar; Rock - rock minerals.

The systematic scans of a large number of polished blocks and grain mounts failed to prove the occurrence of enclosed particulate gold in sulfide minerals from Jinya ore. Homogeneous distribution of gold in arsenopyrite and pyrite indicated by PIXE mapping (Figures 6-8) and "flat" SIMS in-depth concentration profiles (Figure 15) indicate that submicroscopic gold in arsenopyrite and pyrite occurs as structurally bound solid solution gold. Except for realgar, no evidence was found for the occurrence of colloidal gold in arsenopyrite and pyrite, such as has been reported by Bakken et al. (1989) in several minerals from the Carlin gold deposit. Bakken et al. (1989) located discrete native gold particles of 50-200 $\AA$ in diameter encapsulated in pyrite, cinnabar and more rarely, quartz, as well as gold particles of 200-1000 $\AA$ in diameter associated with $1 \mathrm{M}$ illite. 

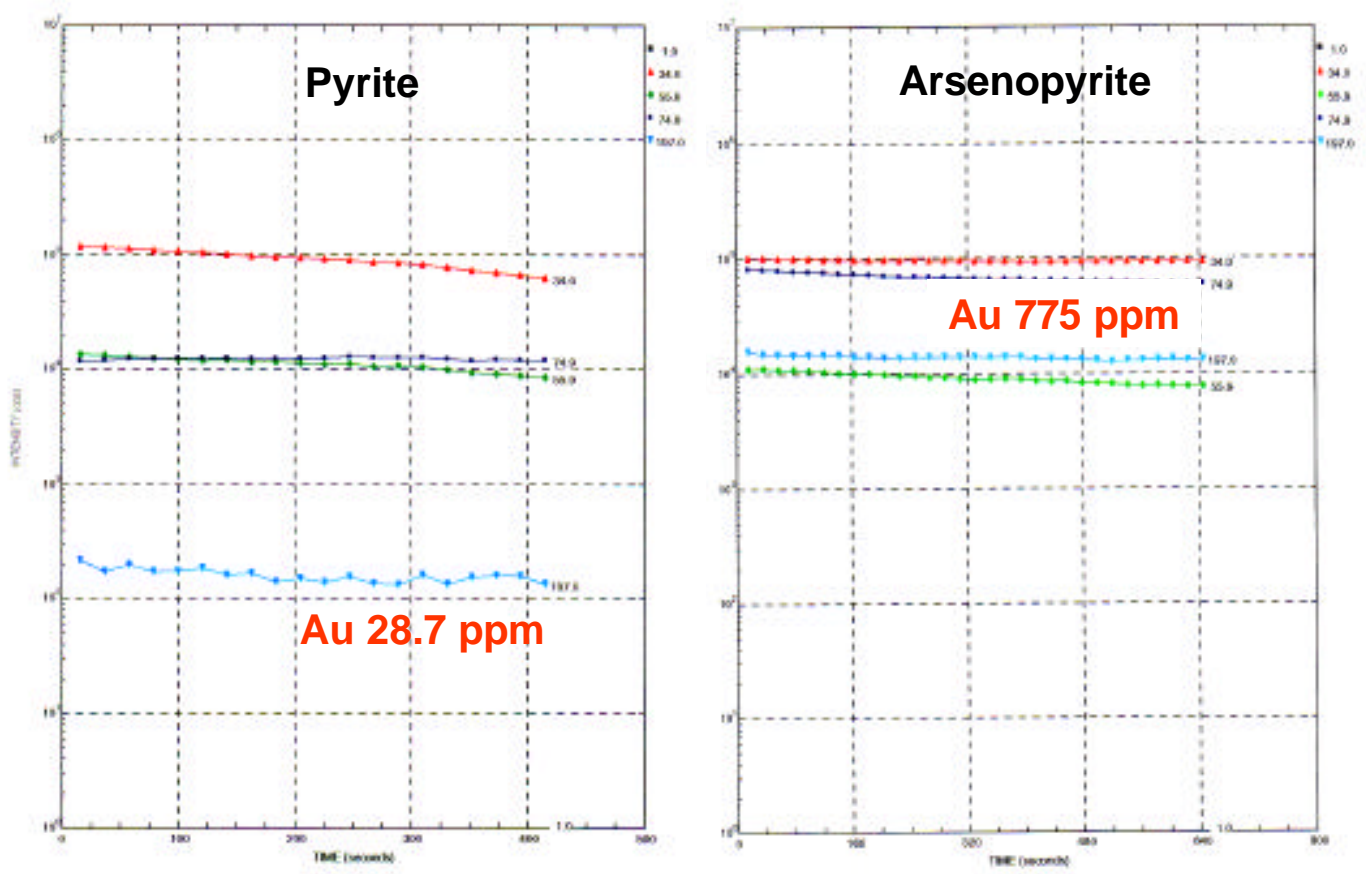

Figure 15: SIMS in-depth concentration profiles of pyrite (left) and arsenopyrite. "Flat" profiles of gold (sky blue) show that gold in pyrite and arsenopyrite occurs as solid solution gold.

Occurrence of significant amount of gold in sulfides in the Jinya ore, particularly in arsenopyrite and pyrite implies that arsenopyritization and pyritization can be used as indication of gold mineralization and as a guide for the further exploration in the Jinya district. The implication of structurally bound gold in the Jinya ore (and in other Carlin-type refractory ores) for gold extraction is that finer grinding will improve the recovery of gold-bearing sulfides by flotation, but will not improve the recovery of gold by conventional cyanidation because gold in sulfides is not accessible to cyanide solution. The ore containing submicroscopic gold in pyrite structure needs to be pretreated to make gold amenable to cyanide leaching. Roasting and pressure-oxidation pretreatment processes are generally used for high-grade refractory ores, such as whole-ore roasting and autoclaving pretreatment in Goldstrike, USA and whole-ore roasting in Minahasa, Indonesia. Generally speaking, low-grade refractory ores containing 1 to $2.5 \mathrm{~g} / \mathrm{t}(0.03$ to $0.07 \mathrm{oz} / \mathrm{st})$ do not contain enough value to justify a milling pretreatment process (Wan, 2001). They can be treated by biooxidation-heap leaching process. Therefore, it is very important to ascertain the mode of occurrence of gold in the ore to be treated prior to process selection and flowsheet development.

\section{Acknowledgements}

We are grateful to Stephen Chryssoulis of AMTEL for his enthusiastic support with the SIMS, RIMS and EPMA analyses, and to Fanqing Li of USTC for help with the SEM, and to Chigang Ren and Shijun Zhou of Fudan University, China for help with the PIXE mapping. We are also grateful to Dr. Jim Hwang, Editor-in-Chief for his helpful comments and suggestions. 


\section{References}

Arehart, G.B., Chryssoulis, S.L., and Kesler, S.E. (1993): Gold and arsenic in iron sulfides from sediment-hosted micron gold deposits: Implications for depositional processes. Econ. Geol., Vol. 88, 171-185.

Bakken, B.M., Hochella, M.F., Jr., Marshall, A.F. \& Turner, A.M. (1989): High-resolution microscopy of gold in unoxidized ore from the Carlin mine, Nevada. Econ. Geol. Vol. 84, 171179.

Bakken, B.M., Fleming, R.H., and Hochella, M.F., Jr. (1991): High-resolution microscopy of auriferous pyrite from the Post deposit, Carlin district, Nevada. In: Process Mineralogy XICharacterization of metallurgical and recycable products, Hausen, D.M., Petruk, W., Hagni, R.D., and Vassiliou, A., eds., Washington, D.C., TMS, p. 13-23.

Boyle, R.W. (1979): The geochemistry of gold and its deposits. Geol. Survey of Canada, Bull. 280.

Cabri, L.J., Chryssoulis, S.L., DE Villiers, J. P.R., Laflamme, J.H.G., and Buseck, R. (1989): The nature of "invisible" gold in arsenopyrite. Can. Mineral., Vol. 27, 353-362.

Chryssoulis, S.L., Cabri, L.J., and Salter, R.S. (1987): Direct determination of invisible gold in refractory sulfide ores. International Symposium on Gold Metallurgy - Refractory Gold, Toronto, Ontario, February 1987, Proceedings, 235-244.

Chryssoulis, S.L., Cabri, L.J., and Lennard, W. (1989): Calibration of the ion microprobe for quantitative trace precious metal analyses of ore minerals. Econ. Geol., Vol. 84, 1684-1689.

Chryssoulis, S.L. and Cabri, L.J. (1990): Significance of gold mineralogical balance in mineral processing. Trans. Instn. Min. Metall., Sec. C: Mineral Process. Extr. Metall. 99, T.T., C1-C10.

Cook, N.J. and Chryssoulis, S.L. (1990): Concentrations of "invisible gold" in the common sulfides. Can. Minerl. Vol. 28, 1-16.

Hausen, D.M. (1981): Process mineralogy of auriferous pyritic ores at Carlin, Nevada. In Hausen, D.M., and Park, W.C., eds., Process Mineralogy, TMS, Warrendale, PA, 271-289.

Hausen, D.M., Ahlrichs, J.W., Mueller, W., and Park, W.C. (1986): Particulate gold occurrences in three Carlin carbonaceous ores. In Process Mineralogy VI, ed. D. Hagni, TMS, Warrendale, PA, 193-214.

Healy, R.E. and Petruk, W. (1990): Petrology of Au-Ag-Hg alloy and 'invisible gold' in the Trout Lake massive sulfide deposit, Flin Flon, Manitoba. Can. Mineral., Vol. 28, 2, 189-206.

Hofstra, A.H., and Cline, J.S. (2000): Characteristics and models for Carlin-type gold deposits. Reviews in Economic Geology, Vol. 13, p. 163-220.

Jory, J. (2002): Stratigraphy and host rock controls of gold deposits of the northern Carlin trend. Nevada Bureau of Mines and Geology, Bulletin 111: Gold Deposits of the Carlin Trend, 20-34.

Kerrich, R., Golsfarb, R., Groves, D., and Garvin, S. (2000): The geodynamics of world-class gold deposits: characteristics, space-time distribution, and origins. Reviews in Economic Geology, Vol. 13, p. 501-551.

Liu, D.S. (1994): The Carlin-type gold deposits in China. Nanjing University Press, Nanjing, pp. 414.

Neumayr, P., Cabri, L.J., Groves, D.I., Mikucki, E.J., and Jackman, J.A. (1993): The mineralogical distribution of gold and relative timing of gold mineralization in two Archean settings of high metamorphic grade in Australia. Can. Mineral., Vol. 31, 711-725.

Peters, S.G. (editor) (2002): Geology, geochemistry, and geophysics of sedimentary-hosted $\mathrm{Au}$ deposits in P.R. China. USGS Open-File Report: 02-131.

Petruk, W. (2000): Applied mineralogy in the mining industry. Elsevier, Amsterdam. 
Radtke, A.S. (1985): Geology of the Carlin gold deposit, Nevada. U.S. Geological Survey Professional Paper 1267, 124 p.

Simon, G., Kesler, S.E. and Chryssoulis, S.L. (1999): Geochemistry and Textures of Gold-bearing Arsenian Pyrite, Twin Creeks, Nevada: Implications for deposition of gold in Carlin-type deposits. Econ. Geol. Vol. 94, 405-422.

Teal, L. and Jackson, M. (2002): Geologic overview of the Carlin Trend gold deposits. Nevada Bureau of Mines and Geology, Bulletin 111: Gold Deposits of the Carlin Trend, 9-19.

Wan, R.Y. (2001): Importance of metallurgical research on refractory gold processing. Mining Engineering, SME, November, p. 41-46.

Wang, K.R., Zhou, Y.Q., Li, F., Sun, L., Wang, J., Ren, C.G., Zhou, S.J., Tang, J.Y., and Yang, F.J. (1992): SPM and SEM study on the occurrence of micrograined gold in the Jinya gold deposit, Guangxi. Chinese Science Bulletin, Vol. 37, 1906-1910.

Wang, K.R. and Zhou, Y.Q. (1993): Invisible gold in sulfide ores from Jinya Carlin-type gold deposit, south China. Resource Geology Special Issue, No. 16, 314-318.

Wang, K.R., Zhou, Y.Q., Sun, L.G. and Ren, C.G. (1994): Study on the gold occurrence from several typical Carlin-type gold deposits in China. Publishing House of University of Science \& Technology of China, Hefei.

Wells, J.D. and Mullens, T.E. (1973): Gold-bearing arsenian pyrite determined by microprobe analyses, Cortez and Carlin mines, Nevada. Econ. Geol., Vol. 68, 187-201.

Yakubchuk, A. (2000): Regional structure similarities of Carlin-type gold mineralization in Nevada, Siberia and South China: a comparison. In Cluer, J.K., Price, J.G., Struhsacker, E.M., Hardyman, R.F., and Morris, C.L., eds., Geology and Ore Deposits 2000: The Great Basin and Beyond, Geol. Society of Nevada Symposium Proceedings, Vol. 1, 549-561. 